\title{
Soil Phosphorus and Corn Development Under Application of Phosphate Sources
}

\author{
Paulo Fernandes Boldrin ${ }^{1}$, Ana Carollina Pereira dos Reis ${ }^{1}$, Vinícius de Mello Benites ${ }^{2}$, \\ Rose Luiza Moraes Tavares ${ }^{1}$, June Faria Scherrer Menezes ${ }^{1} \&$ Veridiana Cardozo Gonçalves Cantão ${ }^{1}$ \\ ${ }^{1}$ Agronomy College, Universidade de Rio Verde, Rio Verde, GO, Brazil \\ ${ }^{2}$ Embrapa Solos, Rio de Janeiro, RJ, Brazil \\ Correspondence: Paulo Fernandes Boldrin, Mestrado em Produção Vegetal, Fazenda Fontes do Saber, Agronomy \\ College, Universidade de Rio Verde, P.O. Box 104, Rio Verde, GO, Zip Code 75901-970, Brazil. Tel: \\ 55-(64)-3611-2214. E-mail: pfboldrin@gmail.com
}

Received: June 23, 2021

Accepted: July 23, 2021

Online Published: August 15, 2021

doi:10.5539/jas.v13n9p61

URL: https://doi.org/10.5539/jas.v13n9p61

The research is financed by University of Rio Verde (UniRV) and the Fundação de Amparo à Pesquisa do Estado de Goiás (FAPEG).

\begin{abstract}
Knowledge of the solubility of phosphate fertilizers is fundamental for phosphorus (P) recommendation management and for choosing the laboratory evaluation method of nutrient availability in the soil according to the history of fertilization. The aim was to evaluate the initial development of corn plants as a function of the application of triple superphosphate (TSP) and natural phosphate of Arraias (NPA) with and without liming and incubation time, as well as to evaluate the available $\mathrm{P}$ in the soil with the use the extractors Mehlich-1 and Mehlich-3. An experiment was installed in an $8 \times 3 \times 2$ factorial scheme, being 8 fertilizer incubation times (180, 140, 100, 80, 60, 40, 20, 0 day(s) before planting), 3 P sources (control-without P, TSP and NPA) and 2 refers to the application of limestone (with and without limestone). Were evaluated the shoot and root dry matter, analysis of $\mathrm{P}, \mathrm{Ca}, \mathrm{Mg}$, and $\mathrm{Zn}$ in shoot and $\mathrm{P}$ in roots. In the soil, $\mathrm{P}$ levels were determined by Mehlich-1 and Mehlich-3 extractors. There was a greater accumulation of $\mathrm{P}$ with the application of TSP with limestone in all incubation times. The application of the NPA allowed a greater accumulation of $\mathrm{P}$ in the plants without the application of lime. The previous incubation of the NPA did not favor the efficiency of this source, neither in the soil with corrected acidity nor in the soil with its original acidity. Mehlich-3 proved to be adequate to determine the phosphorus content in soil fertilized by NPA.
\end{abstract}

Keywords: agronomic efficiency, apatite, arraias phosphate, phosphorus sources

\section{Introduction}

Managing the application of phosphate fertilizers and determining the availability of phosphorus (P) in the soil requires technical knowledge and attention from professionals in the agricultural sector. The addition of the recommended dose will not always result in the desired $\mathrm{P}$ availability, since the forms and degree of the lability of phosphorus vary with the characteristics and properties of the soil (McLaughlin et al., 2011).

Phosphate fertilizers are processed from phosphate rocks and the solubility of the products can vary in high, medium, or low. The use of soluble phosphates allows the immediate release of $\mathrm{P}$, regardless of the form of application. On the other hand, non-acidified natural phosphates, with low solubility, tend to be less efficient, especially when applied in planting for annual crops, which have a high demand for $\mathrm{P}$ in a short time and the release of P in the soil, from these sources, is gradual (Hedley \& McLaughlin, 2005; Novais \& Smith, 1999).

Field and laboratory studies aiming at increasing the efficiency of phosphate rocks indicate that acidic soil conditions, associated with low levels of labile $\mathrm{P}$ and exchangeable in the solution $\mathrm{Ca}$, favor the release of $\mathrm{P}$ contained in these rocks. This is because the acidity condition provides protons for the solubilization of these sources and because they are more suitable for perennial crops, they remain in contact with the soil for a long time, allowing solubilization and utilization by the cultures (Akintokun, Adetunji, \& Akintokun, 2003; Hammond, Chien, \& Easterwood, 1986; Novais \& Mello, 2007). 
The determination of $\mathrm{P}$ available in the soil to plants is due to the dynamics of the nutrient, complex processes, and interactions with different recalcitrance, with iron, aluminum, and calcium (Barber, 1995; Ziadi, Whalen, Messiga, \& Morel, 2013; Rheinheimer, Gatiboni, \& Kaminski, 2008), and the method of P determination used. The methods are based on the use of extractors, such as chemical solutions (Mehlich, 1984), anion exchange resins (Amer, 1955), cation and anion exchange resins (mix) (Raij et al., 1987) and the so-called diffusive gradients in thin films (Menzies, Kusumo, \& Moody, 2005; Six, Smolders, \& Merckx, 2013; Heidari, Reyhanitabar, Oustan, \& Olad, 2016).

In practice, most routine laboratories in Brazil determine the $\mathrm{P}$ available in the soil through chemical solutions, mainly by Mehlich-1 or by ion exchange resin. Mehlich-1 is an efficient extractor that enables good correlation with grain yield (Oliveira, Nunes, Sousa, Busato, \& Figueiredo, 2019). However, the use of the Mehlich-1 method to evaluate the P content in the soil receives some criticism both for underestimating P in clay soils and for overestimating P in soils that receive natural phosphates (Novais \& Smith, 1999). On the other hand, Mehlich-3 minimizes the influence of natural phosphates on the analytical result, in addition to having the advantage of being a multi-element method, and being able to determine, in addition to $\mathrm{P}$, other nutrients such as potassium $(\mathrm{K})$, Calcium $(\mathrm{Ca})$, magnesium $(\mathrm{Mg})$, manganese $(\mathrm{Mn})$, zinc $(\mathrm{Zn})$ and copper $(\mathrm{Cu})$ (Mumbach, Oliveira, Warmling, \& Gatiboni, 2018).

The objective of the work was to evaluate the initial development of corn plants as a function of the application of triple superphosphate and natural phosphate from Arraias, with and without liming and the incubation time, as well as to evaluate the available phosphorus in the soil with the use of extractors Mehlich-1 and Mehlich-3.

\section{Method}

\subsection{Study Descriptions}

The experiment was carried out in pots with soil, in an air-conditioned greenhouse with an evaporative cooling system keeping the temperature between 25 and $30{ }^{\circ} \mathrm{C}$, under natural light and $70 \%$ relative humidity in the municipality of Rio Verde-GO, Brazil (Koppen-Geiger classification $=\mathrm{Aw}$ ).

\subsection{Experimental Design}

The experimental design used was completely randomized, in a factorial scheme $8 \times 3 \times 2$, with four replications, totaling 192 pots. The first factor referring to 8 fertilizer incubation times before planting $(180,140,100,80,60$, 40, 20, 0 day (s) before planting), the second factor refers to the sources of P (control - without P, TSP-triple superphosphate, and NPA - natural phosphate from Arraias) and the third factor refers to the application of limestone (with and without limestone).

\subsection{Conducting the Experiment}

The soil used in the experiment was collected at the University of Rio Verde from the $0-20 \mathrm{~cm}$ layer of an area of native vegetation in the Brazilian Cerrado. The collected soil was sieved and divided into two parts, one without limestone and the other with limestone. For the treatments that received limestone ( $88 \%$ RNV-Relative Neutralizing Value), liming was performed based on the chemical analysis of the soil (Table 1) to raise the base saturation to $60 \%$. It was decided to perform the liming in a single moment before starting the preparation of the pots to guarantee the same minimum reaction time of the liming for all pots, which was carried out and incubated for 30 days maintaining the field capacity of the soil, in plastic bags containing $5 \mathrm{~kg}$ of soil.

Table 1. Attributes of the soil used before the installation of the experiment

\begin{tabular}{|c|c|c|c|c|c|c|c|c|c|c|c|}
\hline $\mathrm{pH}_{\left(\mathrm{CaCl}_{2}\right)}$ & $P$ & $\mathrm{~S}$ & $\mathrm{~K}$ & $\mathrm{Ca}$ & Mg & $\mathrm{Al}$ & $\mathrm{H}+\mathrm{Al}$ & \multirow{2}{*}{$\begin{array}{l}\text { O.M. } \\
\mathrm{g} \mathrm{dm}^{-3}\end{array}$} & Sand & Silt & Clay \\
\hline & & $\mathrm{m}^{-3}---$ & & & $\mathrm{cmol}_{\mathrm{c}}$ & & - & & \multicolumn{3}{|c|}{ - $\%$ - - } \\
\hline 4.0 & 0.3 & 3.6 & 0.11 & 0.57 & 0.34 & 0.75 & 3.75 & 32.6 & 42 & 8 & 50 \\
\hline
\end{tabular}

Note. P: Mehlich-1; O.M: organic matter determination by colorimetric method.

Following the incubation times of 180,140,100, 80, 60, 40, 20, 0 day (s) before planting, the pots containing 2 $\mathrm{kg}$ of soil were prepared according to the other two factors studied. The two groups of soils previously treated with and without liming were used on each preparation date. The sources of $\mathrm{P}$ were applied considering the recommendation of $100 \mathrm{mg} \mathrm{kg}^{-1}$ of $\mathrm{P}$.

The $\mathrm{P}$ dose was determined by previous studies of growth response curves for maize as a function of increasing $\mathrm{P}$ doses, which indicated that $100 \mathrm{mg} \mathrm{kg}^{-1}$ of $\mathrm{P}$ corresponds to a responsive dose to the soil used. The amount 
applied was calculated according to the concentration of total $\mathrm{P}_{2} \mathrm{O}_{5}$ (TSP containing $44 \%$ and NPA containing $14.99 \% \mathrm{P}_{2} \mathrm{O}_{5}$ ), thus, they were applied and incorporated in the total volume of the pots $1.04 \mathrm{~g} \mathrm{pot}^{-1}$ of TSP in granule and $3.05 \mathrm{~g} \mathrm{pot}^{-1}$ of NPA, in powder.

Arraias phosphate is of sedimentary origin extracted from phosphorites from the Sete Lagoas Formation, Bambuí Group, Campos Belos region, GO, and Arraias, TO (Monteiro, 2009).

All pots were irrigated with deionized water, maintained at $60 \%$ of the field capacity, by weighing the pot + soil set, twice a week, being monitored until the day of implantation of the corn crop.

Corn sowing was carried out 180 days after the installation of the first groups of pots, together with the date 0 (zero) of pot preparation for adding the sources of P. Three corn seeds per pot were sown, after germination, thinning was carried out, with one plant remaining in each pot. The corn plants were grown for 45 days.

The plants in all pots were fertilized with nutrient solution, with $150 \mathrm{mg} \mathrm{dm}^{-3}$ of $\mathrm{N} ; 75 \mathrm{mg} \mathrm{dm}^{-3}$ of K; $60 \mathrm{mg} \mathrm{dm}^{-3}$ of $\mathrm{S} ; 3.6 \mathrm{mg} \mathrm{dm}^{-3}$ of $\mathrm{Mn} ; 1.5 \mathrm{mg} \mathrm{dm}^{-3}$ of Cu; $5.0 \mathrm{mg} \mathrm{dm}^{-3}$ of $\mathrm{Zn} ; 0.5 \mathrm{mg} \mathrm{dm}^{-3}$ of B and $0.15 \mathrm{mg} \mathrm{dm}^{-3}$ of Mo, using the sources urea, $\mathrm{KNO}_{3},\left(\mathrm{NH}_{4}\right)_{2} \mathrm{SO}_{4}, \mathrm{MnCl}_{2}, \mathrm{CuSO}_{4}, \mathrm{ZnSO}_{4 \cdot 7} \mathrm{H}_{2} \mathrm{O}, \mathrm{H}_{3} \mathrm{BO}_{3}$ and $\left(\mathrm{NH}_{4}\right)_{6} \mathrm{Mo}_{7} \mathrm{O}_{24}$, according to recommendations of Malavolta (1980) for testing in pots.

\subsection{Plant Phytotechnical Assessments}

Forty-five days after sowing, the plants were separated into the shoot and root parts. The roots were washed and placed in a solution containing $\mathrm{HCl}\left(0.5 \mathrm{~mol} \mathrm{~L}^{-1}\right)$ for 5 minutes and then washed in running water and finished in distilled water. This procedure was carried out to ensure the elimination of excess nutrients and other elements outside the root tissues.

After washing, the shoot and root were dried for three days in a forced air circulation oven at $65^{\circ} \mathrm{C}$, to obtain the shoot dry matter (SDM) and root dry matter (RDM). The SDM and the RDM were combined to determine the total dry matter (TDM). Subsequently, the samples were ground in a 2 mesh Willey mill.

\subsection{Determinations of Nutrient Contents}

With the ground vegetable material, analyzes of the contents of $\mathrm{P}, \mathrm{Ca}, \mathrm{Mg}$, and $\mathrm{Zn}$ in the shoot and $\mathrm{P}$ in the roots were carried out.

The contents of $\mathrm{P}, \mathrm{Ca}, \mathrm{Mg}$ and $\mathrm{Zn}$ in the plant tissue were extracted by nitro-perchloric digestion (Malavolta, Vitti \& Oliveira, 1997). In the extract, the total levels of $\mathrm{Ca}, \mathrm{Mg}$ and $\mathrm{Zn}$ in the samples were determined using atomic absorption spectrophotometer (GBC-Scientific, SavantAA, Dandenong, Victoria, Australia). The P was determined using a colorimetric spectrophotometer (Metash Instruments, V-500 Spectrophotometer, Shanghai, China).

After separating the roots from the soil, a soil sample was taken from each pot to determine the P content in the soil by Mehlich-1 (Teixeira et al., 2017) and using the Mehlich-3 extraction solution according to Mehlich (1984).

With the determination of the contents of $\mathrm{P}$ in the root and shoot, and the dry matter in each part, it was determined the P recovered by the plant through the accumulation of the nutrient in each part and total.

\subsection{Statistical Analysis}

The data obtained were subjected to analysis of variance $(p<0.05)$, mean test using Tukey $(p<0.05)$ and, when significant by the F test $(\mathrm{p}<0.05)$, regression for the sources was applied and limestone in the incubation times evaluated, whether in double or triple interactions. Thus, only significant regressions were plotted in the figures. The SISVAR statistical program (Ferreira, 2019) was used.

\section{Results}

For the variables RDM, the total accumulation of $\mathrm{P}, \mathrm{Ca}$ and $\mathrm{Zn}$ in the shoot and $\mathrm{P}$ in the soil by Mehlich-3, a triple interaction between the three factors was studied. Results showed that sources behave differently in the presence or absence of limestone over time. This behavior was expected since it is known that the reactivity of natural phosphates is strongly controlled by soil $\mathrm{pH}$ and incubation time (Chien \& Menon, 1995). For SDM, TDM, and accumulation of $\mathrm{Mg}$ in the shoot, there was a double interaction between sources of $\mathrm{P}$ and limestone (Table 2).

For the variables SDM (Figure 1A) and TDM (Figure 1B), it was observed that the plants that received the TSP, regardless of the presence or absence of liming, presented averages superior to the NPA and the control. The plants that received the TSP also showed higher averages when the soil received lime in relation to the plants that 
grew in soil without liming, for the variables SDM and TDM (Figures 1A and 1B). However, the plants that received the NPA, presented higher dry matter when they grew in soil without liming (Figure 1).

The plants that grew in the pots with TSP and limestone, presented superior averages of RDM in relation to the plants of the control treatment and fertilized with NPA, in all the incubation times. In the presence of limestone, the treatments fertilized with NPA did not differ from the control (Figure 1C). The NPA supply enabled the higher grew up of RDM compared to control and TSP, in soil with no lime application at zero incubation time. This effect may be related to the supply of $\mathrm{Ca}$ and the slight alkalizing effect of natural phosphates when compared to TSP (Hedley \& McLaughlin, 2005). On dates 20, 100 and 140 for RDM, there was no difference between the means when the plants received the application of NPA and TSP, without application of lime (Figure $1 \mathrm{C})$.

Table 2. Summary of the analysis of variance with mean squares (MS) for the evaluated variables

\begin{tabular}{|c|c|c|c|c|c|c|}
\hline \multirow{2}{*}{ Variation sources } & \multirow{2}{*}{ DF } & \multicolumn{5}{|c|}{ MS } \\
\hline & & SDM & RDM & TDM & P Soil (Meh-1) & P Soil (Meh-3) \\
\hline P Sources (FP) & 2 & $229.97 * *$ & $70.28 * *$ & $554.51^{* *}$ & $1568.60 * *$ & $7048.95 * *$ \\
\hline Limestone & 1 & $36.53 * *$ & $11.18^{* *}$ & $88.14^{* *}$ & $97.99 * *$ & $0.05^{\mathrm{ns}}$ \\
\hline Incubation time (TI) & 7 & $0.38^{\mathrm{ns}}$ & $0.25^{\mathrm{ns}}$ & $0.62^{\mathrm{ns}}$ & $18.51^{* *}$ & $147.24 * *$ \\
\hline $\mathrm{FP} \times$ Limestone & 2 & $76.81^{* *}$ & $30.03 * *$ & $202.84 * *$ & $21.89 * *$ & $29.93 *$ \\
\hline $\mathrm{FP} \times \mathrm{TI}$ & 14 & $0.79^{\mathrm{ns}}$ & $0.38^{* *}$ & $2.08^{\mathrm{ns}}$ & $14.97 * *$ & $116.03 * *$ \\
\hline Limestone $\times \mathrm{TI}$ & 7 & $0.86^{\mathrm{ns}}$ & $0.30^{\mathrm{ns}}$ & $1.61^{\mathrm{ns}}$ & $18.41^{* *}$ & $34.45 * *$ \\
\hline $\mathrm{FP} \times$ Limestone $\times \mathrm{TI}$ & 14 & $0.52^{\mathrm{ns}}$ & $0.45^{* *}$ & $1.41^{\mathrm{ns}}$ & $7.39^{\text {ns }}$ & $26.58 * *$ \\
\hline Error & 144 & 0.67 & 0.16 & 1.18 & 4.84 & 31.19 \\
\hline CV $(\%)$ & - & 18.42 & 15.81 & 15.20 & 18.49 & 21.63 \\
\hline \multirow{2}{*}{ Variation sources } & \multirow{2}{*}{ DF } & \multicolumn{5}{|c|}{ MS } \\
\hline & & Total Accum. P & Shoot Ca Accum. & Shoot Mg Accum. & Shoot Zn Accum. & \\
\hline P Sources (FP) & 2 & $6350.05 * *$ & $288.61 * *$ & $8765.91 * *$ & $29873.98 * *$ & \\
\hline Limestone & 1 & $2576.53 * *$ & $85.02 * *$ & $8070.12 * *$ & $164.92^{\mathrm{ns}}$ & \\
\hline Incubation Time (TI) & 7 & $54.99 * *$ & $5.52 * *$ & $28.33^{\text {ns }}$ & $4699.80^{* *}$ & \\
\hline $\mathrm{FP} \times$ Limestone & 2 & $3940.21 * *$ & $116.35^{* *}$ & $6511.51^{* *}$ & $9995.46^{* *}$ & \\
\hline $\mathrm{FP} \times \mathrm{TI}$ & 14 & $49.12 * *$ & $2.35^{* *}$ & $32.11^{\mathrm{ns}}$ & $1497.66^{* *}$ & \\
\hline Limestone $\times \mathrm{TI}$ & 7 & $59.08 * *$ & $0.78^{\mathrm{ns}}$ & $38.17^{\mathrm{ns}}$ & $539.13 *$ & \\
\hline $\mathrm{FP} \times$ Limestone $\times \mathrm{TI}$ & 14 & $62.72 * *$ & $0.90^{\mathrm{ns}}$ & $30.81^{\mathrm{ns}}$ & $541.80 * *$ & \\
\hline Error & 144 & 21.76 & 0.57 & 35.82 & 251.11 & \\
\hline $\mathrm{CV}(\%)$ & - & 19.34 & 19.98 & 21.34 & 25.04 & \\
\hline
\end{tabular}

Note. $\mathrm{DF}=$ Degree of freedom; $\mathrm{CV}=$ coefficient of variation; $\mathrm{SDM}=$ shoot dry matter; RDM $=$ root dry matter; $\mathrm{TDM}=$ total dry matter; Accum. $=$ accumulation; Meh $=$ Mehlich; $*=$ significant at $5 \% ; * *=$ significant at $1 \%$; ns $=$ not significant.

The plants that received the application of TSP, presented higher averages for RDM when they grew in soil with the application of lime compared to the plants that grew in soil without application of lime, in all the evaluated dates. The opposite was observed for plants fertilized with NPA, when compared with and without the application of lime, at 0, 20, 40, 100, and 140 days (Figures 1C).

A regression adjustment $(\mathrm{F}$ test, $\mathrm{p}<0.05)$ was observed for the RDM in the function of the incubation time, both for plants that received TSP with lime and for plants that received NPA without limestone (Figure 1C). There was an increase in the RDM until approximately 87 days when the plants received the TSP with limestone. On the other hand, when the plants received NPA without limestone, there was a decrease in RDM until approximately 136 days (Figure 1C). 

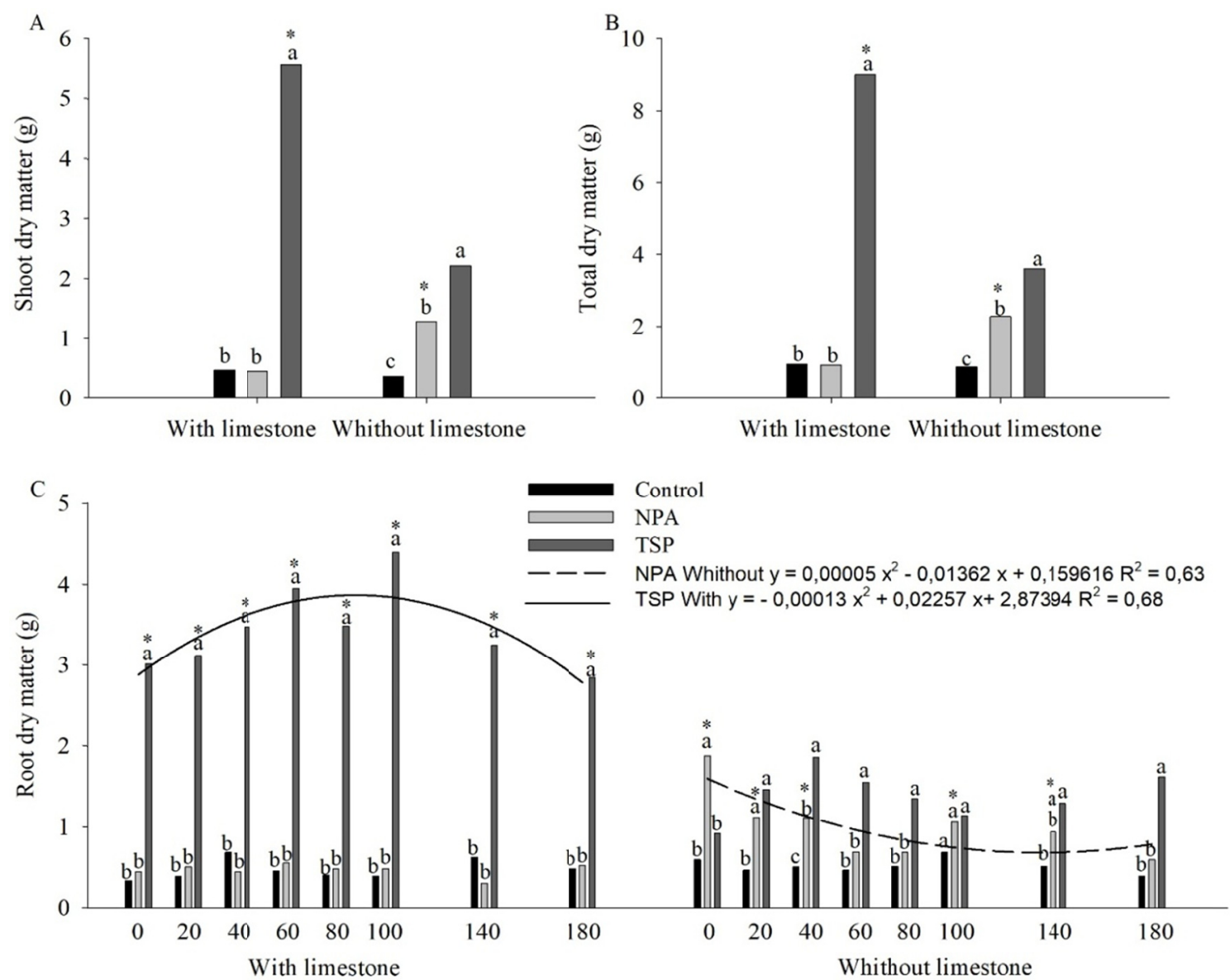

Figure 1. Shoot dry matter (A) and total dry matter (B), depending on the application of limestone in the different sources of P. Root dry matter (C) as a function of incubation time $(0,20,40,60,80,100,140$, and 180 days) for with and without limestone in the different sources of P. Control (without application of P), NPA = natural phosphate from Arraias, and TSP = triple superphosphate. For graphs A and B, averages followed by the same letter, compare the sources of $\mathrm{P}$ for the same group of limestone (with or without). * Indicate a significant difference between with and without limestone, for the same source. For graph $\mathrm{C}$, means followed by the same

letter, compare the sources of $\mathrm{P}$, for the same date and the same application of limestone, with or without, separately. * Indicate a significant difference between with and without limestone, for the same source of $\mathrm{P}$ and the incubation time. (Tukey, $\mathrm{p}<0.05$ )

For the P content in the soil determined by Mehlich-1, the NPA, both with the application of lime and in the absence of lime, provided a higher content of P in the soil, compared to the TSP and the control. TSP presented a higher content than control. The $\mathrm{P}$ content in the soil was higher for both sources when the pots received the application of limestone (Figure 2A). For the $\mathrm{P}$ content in the soil, there was no significant regression adjustment ( $F$ test, $\mathrm{p}<0.05$ ) for incubation times in both sources of $\mathrm{P}$ and control. On the other hand, verifying the effect of $\mathrm{P}$ sources for each pot preparation date, it was found that on all dates the NPA had a higher P content in the soil compared to the TSP and the control, except for 60 days, there was no difference between the sources. The TSP had a higher $\mathrm{P}$ content in the soil than the control in all incubation times (Figure 2B).

The $\mathrm{P}$ content in the soil determined by Mehlich-3 (Figure 2C), shows a significantly higher effect of the TSP with the NPA and the control in all incubation times for both with and without application of lime. In incubation times 0,20 and 60 days the application of NPA allowed a higher content of P in the soil by Mehlich-3 with the application of lime, not expected, at 100 days, the highest content of $\mathrm{P}$ was observed without the application of lime. 


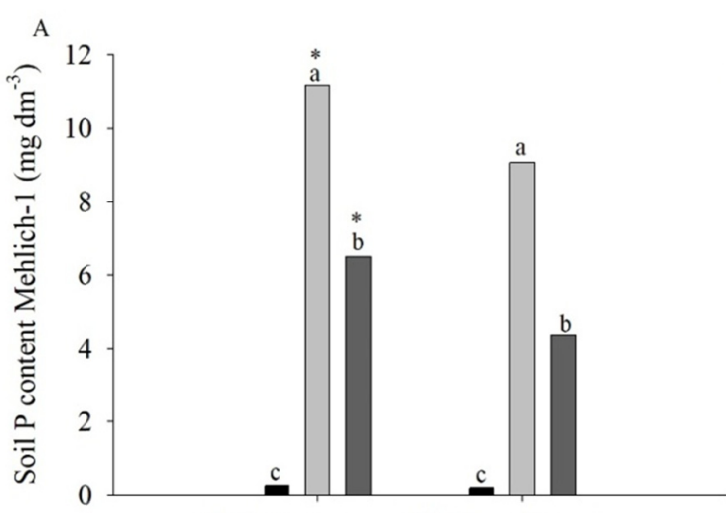

With limestone Whithout limestone

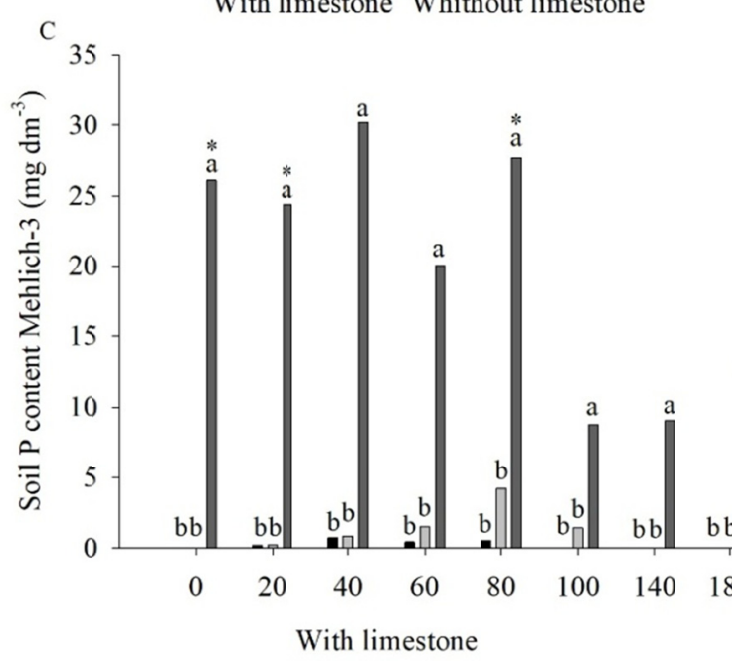

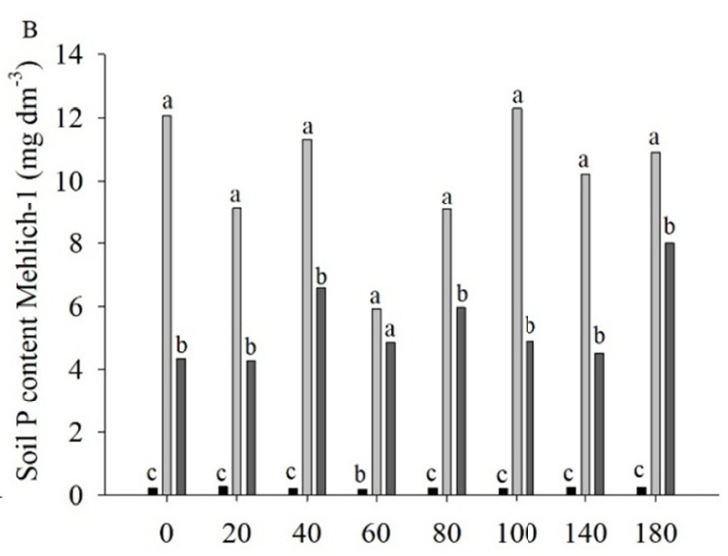
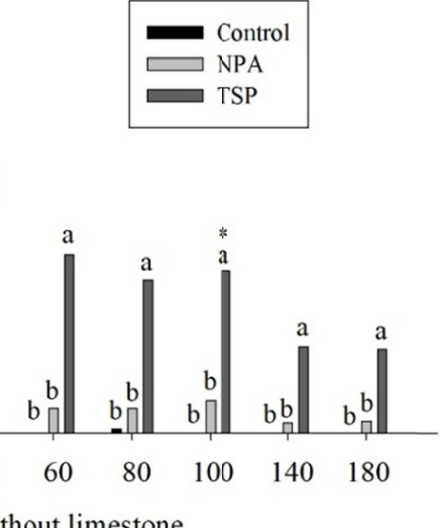

Whithout limestone

Figure 2. P content in the soil determined by Mehlich-1 as a function of limestone application (A) and as a function of incubation time $(0,20,40,60,80,100,140$, and 180 days) (B). P content in the soil determined by Mehlich-3 (C) as a function of the incubation time (0, 20, 40, 60, 80, 100, 140, and 180 days) for with and without limestone in the different sources of P. Control (without application of P), NPA = natural phosphate from Arraias, and TSP = triple superphosphate. For graph (A), means followed by the same letter, compare the sources of $\mathrm{P}$ for the same group of limestone (with or without). * Indicate a significant difference between with and without limestone, for the same source. For graph (B), means followed by the same letter, compare the sources of $\mathrm{P}$ in the same incubation time. For graph (C) averages followed by the same letter, compare the sources of $\mathrm{P}$,

for the same incubation time and the same application of limestone, with or without, singly. ${ }^{*}$ Indicate a significant difference between with and without limestone, for the same source of $\mathrm{P}$ and the incubation time.

(Tukey, $\mathrm{p}<0.05$ )

To visualize the effect of the Mehlich-1 and Mehlich-3 extractor on the efficiency of the use of P sources, depending on the solubility of the source and the presence or absence of limestone, the correlation between the $\mathrm{P}$ content in the soil by Mehlich-1 or Mehlich-3 and the total accumulation of $\mathrm{P}$ in the plant (Figure 3). Thus, even Mehlich-1 showing high levels of P in the soil for NPA, with or without the application of lime, the absorption of $\mathrm{P}$ by the plants did not occur, evidenced by the low accumulation of $\mathrm{P}$ (Figure 3B). However, the Mehlich-3 shows that the high levels in the soil for TSP, mainly with the application of lime, are consistent with the largest accumulations P observed (Figure 3C).

For the accumulation of $\mathrm{Ca}$ in the shoot, there was an interaction between sources of $\mathrm{P}$ and limestone, sources of $\mathrm{P}$ and dates, and limestone and dates (Table 2). The TSP, both with and without the application of lime, provided a greater accumulation of $\mathrm{Ca}$ in the aerial part of the plants, compared to the NPA and the control, whereas the NPA, without application of lime, was greater than the control. The accumulation of $\mathrm{Ca}$ in the shoot was greater for TSP and control when the vessels received the application of lime, compared to the vessels that did not receive limestone and the opposite was observed for the NPA, that is, greater accumulation of Ca when the vessels did not receive limestone (Figure 4A). 

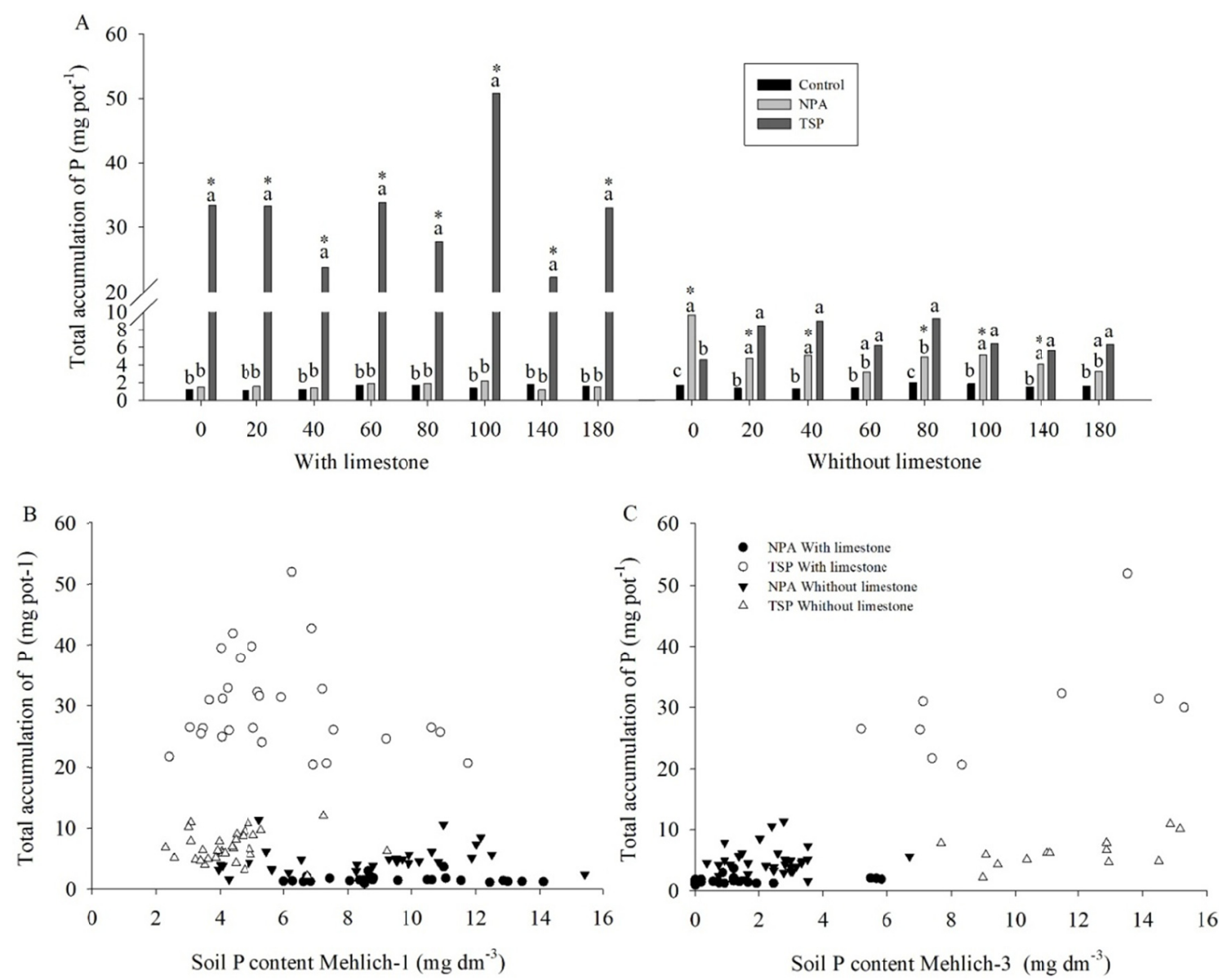

Figure 3. Total accumulation of $\mathrm{P}$ in corn plants (A) as a function of incubation time $(0,20,40,60,80,100,140$, and 180 days) for with and without lime in the different sources of $\mathrm{P}$. Correlations between the $\mathrm{P}$ content in the

soil by Mehlich-1 (B) and Mehlich-3 (C) and the total accumulation of $\mathrm{P}$ in the plant. Control (without application of P), NPA = natural phosphate from Arraias, and TSP = triple superphosphate. Averages followed by the same letter, compare the sources of $\mathrm{P}$, for the same incubation time and the same application of limestone, with or without, singly. * Indicate a significant difference between with and without limestone, for the same source of $\mathrm{P}$ and incubation time. (Tukey, $\mathrm{p}<0.05$ )

There was a significant regression adjustment $(\mathrm{F}$ test, $\mathrm{p}<0.05)$ for the incubation time, only for the TSP source (Figure 4B). An increase in the accumulation of $\mathrm{Ca}$ until the incubation time of approximately 84 days was observed, after that period the availability of $\mathrm{Ca}$ decreased, which was reflected in the accumulation of the nutrient in the shoot. Checking the effect of $\mathrm{P}$ sources for each incubation time, it was found that on all pot preparation dates, the plants that received the TSP showed greater $\mathrm{Ca}$ accumulation in the shoot in comparison to NPA and the control. The NPA provided a greater accumulation of $\mathrm{Ca}$ in the shoot of the plants than the control at $0,80,140$, and 180 days (Figure 4B). 

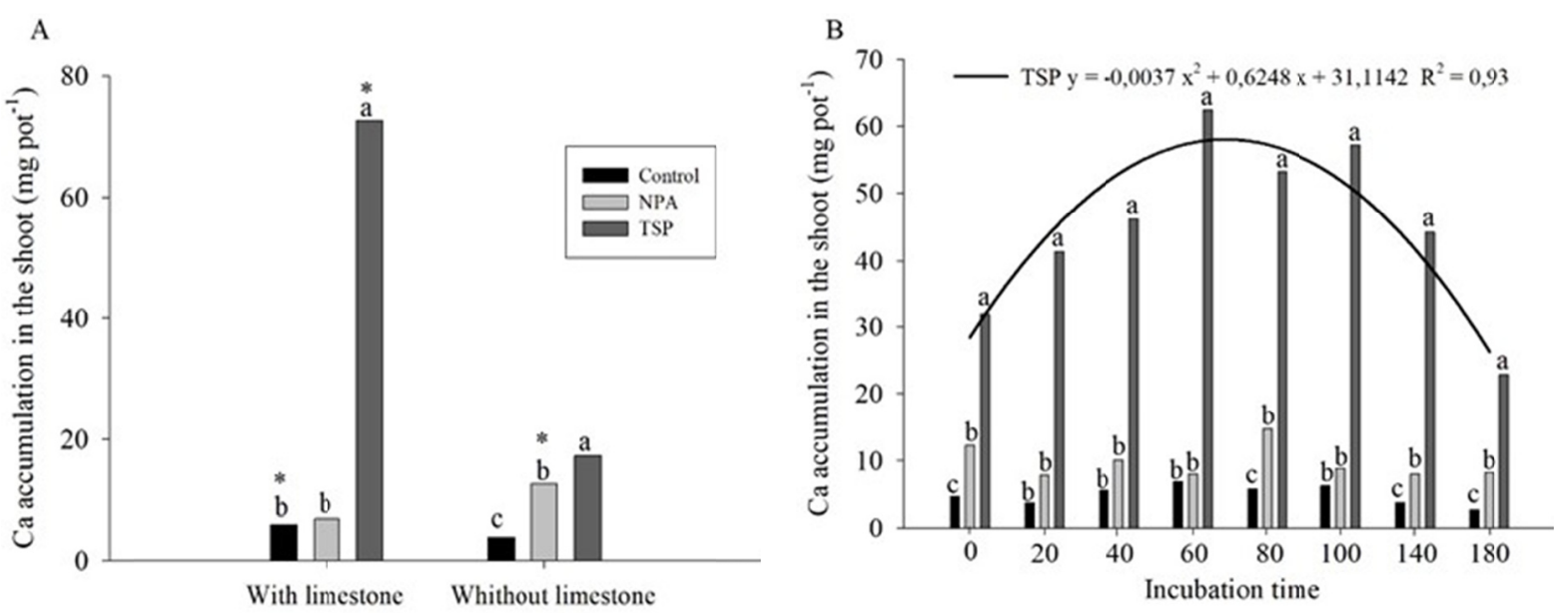

Figure 4. Ca accumulation in the shoot as a function of the limestone application (A) and as a function of the incubation time (B) for the different sources of P. Control (without P application), NPA = natural phosphate from Arraias, and TSP = triple superphosphate. For graph (A), means followed by the same letter, compare the sources of $\mathrm{P}$ for the same group of limestone (with or without). * Indicate a significant difference between with and without limestone, for the same source. For graph (B), means followed by the same letter, compare the sources of $\mathrm{P}$ in the same incubation time. When significant ( $\mathrm{F}$ test, $\mathrm{p}<0.05$ ), regression adjustment was applied.

(Tukey, $\mathrm{p}<0.05$ )

The accumulation of Mg in the shoot in plants was greater for TSP, both in the presence and absence of limestone compared to the NPA and control. The accumulation of Mg in the shoot was greater for the plants that received TSP and control with lime compared to the absence of the application of lime (Figure 5A).

For the accumulation of $\mathrm{Zn}$ in the shoot, there was no significant adjustment of regression $(\mathrm{F}$ test, $\mathrm{p}<0.05)$ for the incubation time in the two sources of $\mathrm{P}$ and control, in the two limestone situations (with or without). Analyzing the effect of the sources of $\mathrm{P}$ within each incubation time, it was observed that on all dates, the plants that developed in the pots that received TSP, with lime, presented higher averages than the plants that received NPA and control and, being that the NPA showed no significant difference when compared to the control (Figure 5B). Plants that developed in pots without lime application showed, at 0,80 , and 180 days, higher mean $\mathrm{Zn}$ accumulation when they received NPA compared to control and at 40,60, 80,100,140, and 180 days when they received TSP concerning control. At all incubation times evaluated, there was no significant difference between TSP and NPA (Figure 5B).

For the accumulation of $\mathrm{Zn}$ in the shoot, there was a significant regression adjustment $(\mathrm{F}$ test, $\mathrm{p}<0.05)$ in the incubation time for the TSP with and without lime and for the NPA without lime. In general, there was an increase in $\mathrm{Zn}$ accumulation up to approximately 99, 108 and 111 days for TSP with lime, TSP without lime and NPA without lime, respectively (Figure 5B). 


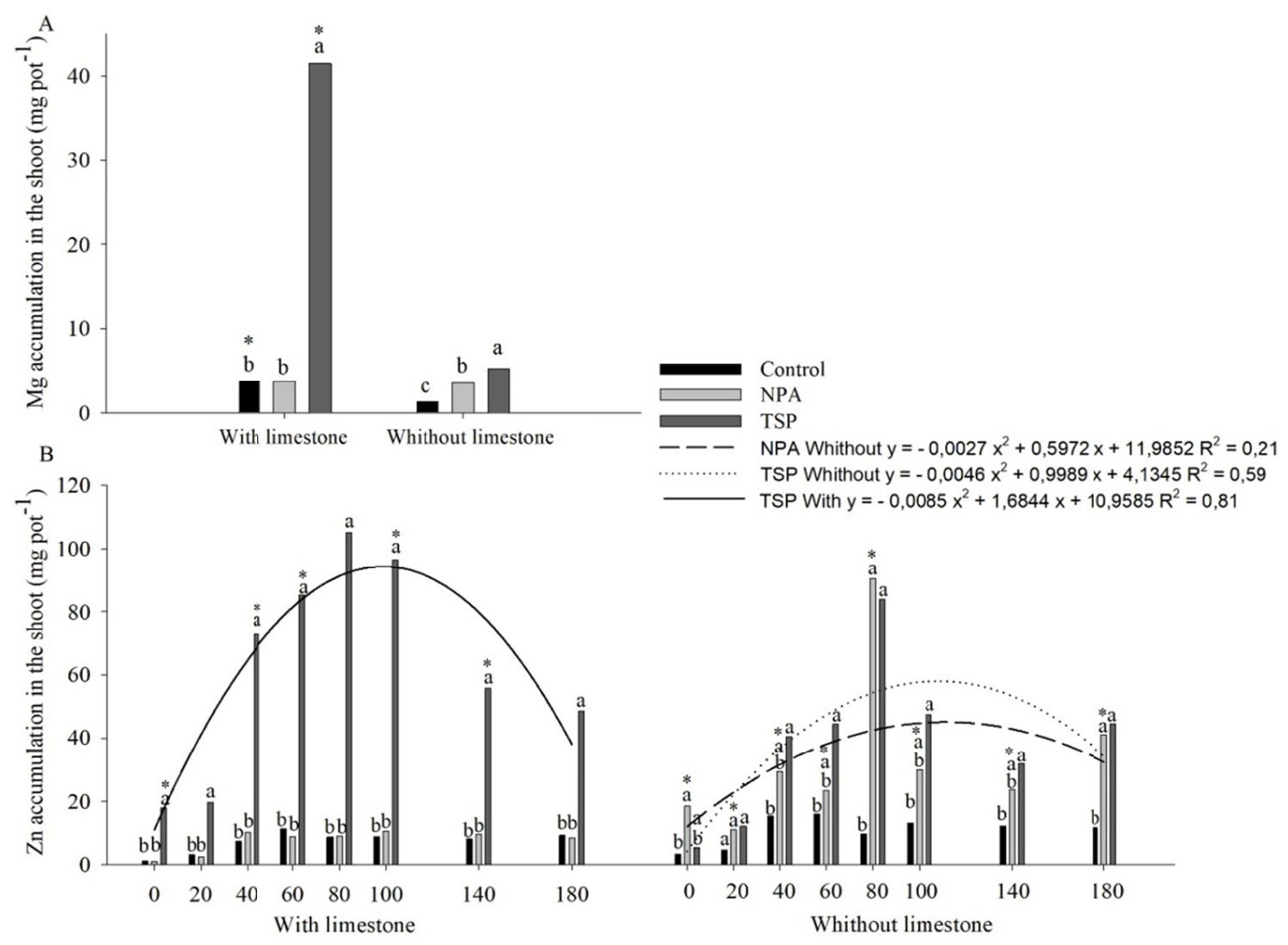

Figure 5. Accumulation of $\mathrm{Mg}$ in the shoot as a function of the limestone application (A), accumulation of $\mathrm{Zn}$ in the shoot (B) as a function of the incubation time $(0,20,40,60,80,100,140$, and 180 days) with and without limestone in the different sources of P. Control (without application of P), NPA = natural phosphate from Arraias, and TSP $=$ triple superphosphate. For graph (A), means followed by the same letter, compare the sources of P for the same group of limestone (with or without). * Indicate a significant difference between with and without limestone, for the same source. For graph (B), means followed by the same letter (Tukey, $p<0.05$ ), compare the sources of $\mathrm{P}$, for the same incubation time and the same application of limestone, with or without, alone. * Indicate a significant difference between with and without limestone, for the same source of $\mathrm{P}$ and incubation time. When significant $(\mathrm{F}$ test, $\mathrm{p}<0.05)$, regression adjustment was applied

\section{Discussion}

The effects observed in SDM, RDM and TDM are justified because the TSP is a source of P with high solubility in water, thus the $\mathrm{P}$ is readily available in the soil solution, explaining the effects in the parameters evaluated. For NPA, which is a source of low water solubility, even presenting a lower performance for these variables compared to TSP in plants that grew with or without limestone, the best responses to NPA are observed in soil without limestone, in an acid medium. Franzini, Muraoka, Coraspe-Leon, and Mendes (2009) also observed greater efficiency of the TSP in providing P for the corn plants, in comparison to the natural phosphates.

The NPA showed a very low-efficiency index when compared to TSP in soil with corrected acidity, and corn dry matter production in treatments with NPA did not differ from the control treatment without P. The low efficiency of Brazilian natural phosphate has been reported by several authors, who report the residual effect of these materials in the following cycles (Novais \& Smith, 1999; Sousa \& Lobato, 2003). Conversely, in the soil without liming, the NPA presented average relative efficiency of the incubation times of $64 \%$ in relation to the TSP, suggesting that this source can be a good alternative in systems where lime is not applied, as in pastures, for example.

The results of determination of $\mathrm{P}$ content in the soil by the Mehlich-1 and Mehlich-3 methods (Figure 2) confirm that the Mehlich-1 method cannot be used to evaluate the P content in the soil in treatments that receive phosphates (Novais \& Smith, 1999) since the method uses an acid solution consisting of two strong acids (HCl and $\mathrm{H}_{2} \mathrm{SO}_{4}$ ), and can overestimate $\mathrm{P}$ bound to $\mathrm{Ca}$ in the soil, so quantities of non-labile $\mathrm{P}$ can be extracted (Novais \& Smith, 1999). 
This overestimation effect of P levels by the Mehlich-1 method can be confirmed in this work, observing the results of the $\mathrm{P}$ content in the soil (Figure 2) as already mentioned, but also in the total P content in plants, presented through the total accumulation of $\mathrm{P}$ (Figure 3A). Despite the higher levels of $\mathrm{P}$ in the soil determined by Mehlich-1 were for NPA, the effect of this higher content of P in the soil on the growth of corn plants was not observed. The opposite was observed, the TSP provided the plants with greater SDM, RDM, and TDM (Figure 1). Hence, the Mehlich-3 method adequately represents the $\mathrm{P}$ content in the soil, evidenced in the growth responses of the plants and the highest total accumulations of $\mathrm{P}$ when the plants were fertilized with TSP.

The use of Mehlich-1 to evaluate the $\mathrm{P}$ content in the soil fertilized with natural phosphates overestimated the $\mathrm{P}$ content in the soil (Schlindwein, Bortolon, \& Gianello, 2011). Similar results have also been reported in other studies, showing higher values extracted by Mehlich-1 compared to Mehlich-3 (Steiner, Lana, Zoz, Frandoloso, \& Fey, 2012).

Although both TSP and NPA have Ca in the constitution, the greatest effect of Ca availability and accumulation in plants was found for the TSP with lime, for the NPA without lime, and for the control treatment with the application of lime. The effect of the solubilization of the sources due to the application of limestone influences the availability of the nutrient. Nakagawa and Rosolem (2005) observed an increase in Ca accumulation for increasing doses of TSP in limed soil.

The interaction between $\mathrm{P}$ and $\mathrm{Zn}$ is known, therefore, the presence of $\mathrm{P}$ can increase the absorption of $\mathrm{Zn}$ by plants, however, a negative interaction can also occur, which in conditions of high concentration of $\mathrm{P}$, and low concentration of Zn, P can induce Zn deficiency (Cakmak \& Marschner, 1987). In this sense, when the level of $\mathrm{Zn}$ is increased, even with high doses of $\mathrm{P}$, the plant absorbs more $\mathrm{Zn}$.

Carneiro et al. (2008), observed that there was an interaction between the sources of P (TSP and reactive phosphate from Arad) and modes of application (scattering and in-furrow), for the $\mathrm{Zn}$ contents and for the $\mathrm{P} / \mathrm{Zn}$ ratio in the leaves of corn, where the application of TSP, mainly when applied to the sowing furrow, provided lower $\mathrm{Zn}$ contents and a higher $\mathrm{P} / \mathrm{Zn}$ ratio, when compared to Arad's reactive phosphate.

With the results of this work, it was possible to notice that all the factors addressed: different sources of $\mathrm{P}$, absence, and presence of limestone and incubations times, present interactions among themselves and interfered in the availability and shoot accumulation of $\mathrm{Ca}, \mathrm{Mg}$, and $\mathrm{Zn}$ in the plants.

For future research, we suggest evaluating the increase of the incubation time or evaluations of long-term agricultural production systems that might show different $\mathrm{P}$ fractions behaviors in soils. The appraisal of $\mathrm{P}$ fractionation, mainly in Oxisoils, to advance the knowledge about the distribution of organic and inorganic fractions, concerning sources solubility, $\mathrm{pH}$ and lime application, incubation time, and in other crops.

\section{Conclusions}

The sources of phosphorus studied showed different behaviors when subjected to the presence and absence of limestone. Triple superphosphate should be used in soils with corrected acidity, while natural phosphate from Arraias has better performance in acidic soils.

There was a greater accumulation of phosphorus with the application of triple superphosphate with limestone in all incubation times. The application of the natural phosphate from Arraias allowed a greater accumulation of phosphorus in the corn plants without the application of lime.

The previous incubation of the natural phosphate did not favor the efficiency of this source, neither in the soil with corrected acidity nor in the soil with its original acidity.

With or without the lime application and for all the incubation time (until 180 days), the Mehlich-1 overestimated the phosphorus content in the soil fertilized by natural phosphate from Arraias, however, for the same source, Mehlich-3 proved to be adequate to determine the phosphorus content in the soil.

\section{Acknowledgements}

The authors are grateful for the financial support and scholarships provided by the University of Rio Verde (UniRV) and by the Fundação de Amparo à Pesquisa do Estado de Goiás (FAPEG). This study was financed in part by the Coordenação de Aperfeiçoamento de Pessoal de Nível Superior-Brasil (CAPES).

\section{References}

Akintokun, O. O., Adetunji, M. T., \& Akintokun, P. O. (2003). Phosphorus availability to soybean from an indigenous phosphate rock sample in soils from southwest Nigeria. Nutrient Cycling in Agroecosystems, 65(1), 35-41. https://doi.org/10.1023/A:1021890121940 
Amer, F., Boulbin, D. R., Black, C. A., \& Duke, F. R. (1955). Characterization of soil phosphorus by anion exchange resin absorption and 32P equilibration. Plant and Soil, 6(4), 391-408. https://doi.org/ 10.1007/BF01343648

Barber, S. A. (1995). Soil nutrient bioavailability: a mechanistic approach (2nd ed.). New York, NY: John Wiley \& Sons. Retrieved from https://www.wiley.com/en-us/Soil+Nutrient+Bioavailability\%3A+A+Mechanistic + Approach\%2C+2nd+Edition-p-9780471587477

Cakmak, I., \& Marschner, H. (1987). Mechanism of phosphorus-induced zinc deficiency in cotton. III. Changes in physiological availability of zinc in plants. Physiologia Plantarum, 70(1), 13-20. https://doi.org/ 10.1111/j.1399-3054.1987.tb08690.x

Carneiro, L. F., Furtini Neto, A. E., Resende, A. V., Curi, N., Santos, J. Z. L., \& Lago, F. J. (2008). Fontes, doses e modos de aplicação de fósforo na interação fósforo-zinco em milho. Ciência e Agrotecnologia, 32(4), 1133-1141. https://doi.org/10.1590/S1413-70542008000400015

Chien, S. H., \& Menon, R. G. (1995). Factors affecting the agronomic effectiveness of phosphate rock for direct application. Fertilizer Research, 41(1), 227-234. https://doi.org/10.1007/BF00748312

Ferreira, D. F. (2019). Sisvar: A computer analysis system to fixed effects split plot type designs. Revista Brasileira de Biometria, 37(4), 529-535. https://doi.org/10.28951/rbb.v37i4.450

Franzini, V. I., Muraoka, T., Coraspe-Leon, H. M., \& Mendes, F. L. (2009). Eficiência de fosfato natural reativo aplicado em misturas com superfosfato triplo em milho e soja. Pesquisa Agropecuária Brasileira, 44(9), 1092-1099. https://doi.org/10.1590/S0100-204X2009000900004

Hammond, L. L., Chien, S. H., \& Easterwood, G. W. (1986). Agronomic effectiveness of Bayovar phosphate rock in soil with induced phosphorus retention. Soil Science Society of America Journal, 50(6), 1601-1606. https://doi.org/10.2136/sssaj1986.03615995005000060044x

Hedley, M., \& McLaughlin, M. (2005). Reactions of Phosphate Fertilizers and By-Products in Soils. In J. T. Sims, \& A. N. Sharpley (Eds.), Phosphorus: Agriculture and the environment. Agronomy Monograph (pp. 181-252). Madison: American Society of Agronomy, Inc., Crop Science Society of America, Inc., Soil Science Society of America, Inc. https://doi.org/10.2134/agronmonogr46.c7

Heidari, S., Reyhanitabar, A., Oustan, S., \& Olad, A. (2016). New Method of Preparing Gel for DGT Technique and Application to the Soil Phosphorus Availability Test. Communications in Soil Science and Plant Analysis, 47(10), 1239-1251. https://doi.org/10.1080/00103624.2016.1166248

Malavolta, E. (1980). Elementos da nutrição mineral de plantas. São Paulo, SP: Ceres.

Malavolta, E., Vitti, G. C., \& Oliveira, S. A. (1997) Avaliação do estado nutricional das plantas: Princípios e aplicações (2nd ed.). Piracicaba, SP: POTAFOS.

McLaughlin, M. J., McBeath, T. M., Smernik, R., Stacey, S. P., Ajiboye, B., \& Guppy, C. (2011). The chemical nature of $\mathrm{P}$ accumulation in agricultural soils-Implications for fertiliser management and design: An Australian perspective. Plant and Soil, 349(1), 69-87. https://doi.org/10.1007/s11104-011-0907-7

Mehlich, A. (1984). Mehlich 3 soil test extractant: A modification of Mehlich 2 extractant. Communications in Soil Science and Plant Analysis, 15(12), 1409-1416. https://doi.org/10.1080/00103628409367568

Menzies, N. W., Kusumo, B., \& Moody, P. W. (2005). Assessment of P availability in heavily fertilized soils using the diffusive gradient in thin films (DGT) technique. Plant and Soil, 269(1), 1-9. https://doi.org/ $10.1007 / \mathrm{s} 11104-004-1725-\mathrm{y}$

Monteiro, C. M. (2009). Fosforitos do Grupo Bambui na região de Campos Belos (GO)/Arraias (TO), na borda oeste do Cráton São Francisco. Brasília, DF: Universidade de Brasília. Retrieved from https://repositorio. unb.br/handle/10482/4898

Mumbach, G. L., Oliveira, D. A., Warmling, M. I., \& Gatiboni, L. C. (2018). Quantificação de fósforo por Mehlich-1, Mehlich-3 e resina trocadora de ânions em solos com diferentes teores de argila. Revista Ceres, 65(6), 546-554. https://doi.org/10.1590/0034-737X201865060010

Nakagawa, J., \& Rosolem, C. A. (2005). Teores de nutrientes na folha e nos grãos de aveia-preta em função da adubação com fósforo e potássio. Bragantia, 64(3), 441-445. https://doi.org/10.1590/S0006-87052005 000300014 
Novais, R. F., \& Mello, J. W. V. (2007). Relação Solo-Planta. In R. F. Novais, V. V. H. Alvarez, N. F. Barros, R. L. F. Fontes, R. B. Cantarutti, \& J. C. L. Neves (Eds.), Fertilidade do solo (pp. 133-204). Viçosa, MG: Sociedade Brasileira de Ciência do Solo.

Novais, R. F., \& Smith, T. J. (1999). Fósforo em solo e planta em condições tropicais (1st ed.). Viçosa, MG: Editora da Universidade Federal de Viçosa.

Oliveira, L. E. Z., Nunes, R. de S., Sousa, D. M. G., Busato, J. G., \& Figueiredo, C. C. (2019). Response of Maize to Different Soil Residual Phosphorus Conditions. Agronomy Jornal, 111(6), 3291-3300. https://doi.org/10.2134/agronj2018.11.0710

Raij, B. V., Quaggio, J. A., Cantarela, H., Ferreira, M. E., Lopes, A. S., \& Bataglia, O. C. (1987). Análise química de solos para fins de fertilidade (1st ed.). Campinas, SP: Fundação Cargill.

Rheinheimer, D. S., Gatiboni, L. C., \& Kaminski, J. (2008). Fatores que afetam a disponibilidade do fósforo e o manejo da adubação fosfatada em solos sob sistema plantio direto. Ciência Rural, 38(2), 576-586. https://doi.org/10.1590/S0103-84782008000200049

Schlindwein, J. A., Bortolon, L., \& Gianello, C. (2011). Soil phosphorus available for crops and grasses extracted with three soil-test methods in Southern Brazilian soils amended with phosphate rock. Communications in Soil Science and Plant Analysis, 42(3), 283-292. https://doi.org/10.1080/00103624. 2011.538881

Six, L., Smolders, E., \& Merckx, R. (2013). The performance of DGT versus conventional soil phosphorus tests in tropical soils-maize and rice responses to P application. Plant and Soil, 366(1), 49-66. https://doi.org/ 10.1007/s11104-012-1375-4

Sousa, D. M. G., \& Lobato, E. (2003). Adubação fosfatada em solos da região do Cerrado (Informações Agronômicas, 102). Piracicaba, SP: Potafos. Retrieved from http://www.ipni.net/publication/ia-brasil.nsf/0/ 78429ADDBF7C6D5183257AA2005C6827/\$FILE/ENCARTE102.PDF

Steiner, F., Lana, M. do C., Zoz, T., Frandoloso, J. F., \& Fey, R. (2012). Extraction methods and availability of phosphorus for soybean in soils from Paraná State, Brazil. Semina: Ciências Agrárias, 33(3), 1005-1014. https://doi.org/10.5433/1679-0359.2012v33n3p1005

Teixeira, P. C., Donagemma, G. K., Fontana, A., \& Teixeira, W. G. (2017). Manual de métodos de análise do solo (3rd ed.). Brasília, DF: Embrapa. Retrieved from https://www.infoteca.cnptia.embrapa.br/handle/ doc/1085209

Ziadi, N., Whalen, J. K., Messiga, A. J., \& Morel, C. (2013) Assessment and modeling of soil available phosphorus in sustainable cropping systems. In D. L. Sparks (Ed.), Advances in Agronomy (pp. 85-126). Burlington, MA: Academic Press. https://doi.org/10.1016/B978-0-12-417187-9.00002-4

\section{Copyrights}

Copyright for this article is retained by the author(s), with first publication rights granted to the journal.

This is an open-access article distributed under the terms and conditions of the Creative Commons Attribution license (http://creativecommons.org/licenses/by/4.0/). 